\title{
Nuclear Thyroid Hormone Receptors
}

\author{
Mitchell A. Lazar * and William W. Chin* \\ *Departments of Medicine and Human Genetics, University of Pennsylvania School of Medicine, Philadelphia, Pennsylvania 19104; \\ and ${ }^{\ddagger}$ Division of Genetics, Department of Medicine, Brigham and Women’s Hospital and Howard Hughes Medical Institute, \\ Harvard Medical School, Boston, Massachusetts 02115
}

Thyroid hormones (L-T3 and L-T4) are important for nearly all human tissues. They have profound effects on metabolic rate and oxygen consumption, but also have unique functions in a variety of organs, including the heart, liver, and pituitary gland, which reflect the specialized nature of these systems. Many of the effects of thyroid hormone occur at the level of gene expression, and are mediated by nuclear thyroid hormone receptors (TR) ${ }^{1}$ (1). Evidence for the existence and importance of nuclear TRs with high affinity and specificity for T3 has been recently reviewed by Oppenheimer et al. (2) and, in this journal, by Samuels et al. (3). The purpose of this Perspective is to provide an up-to-date summary of new knowledge that has directly resulted from the cloning of multiple TRs and related molecules.

\section{Thyroid hormone receptors are protooncogene products related to steroid and retinoic acid receptors}

A major breakthrough in our understanding of T3 action occurred when Sap et al. (4) and Weinberger et al. (5) simultaneously discovered that c-erbA, the product of the cellular homologue of the viral oncogene $v$-erbA (6), has the ability to bind T3 with great affinity and specificity. It had previously been noted that $v$-erb $A$ was structurally related to the glucocorticoid, estrogen, and progesterone receptors (7-11). Subsequently, receptors for mineralocorticoids (12), androgens (13, $14)$, vitamin $D(15,16)$, and retinoic acid $(17,18)$ were determined to have similar structures. Thus, the TR is a member of a superfamily of intracellular hormone receptors $(19,20)$. Each receptor interacts with its cognate hormone as well as with the subset of genes responsive to that hormone. DNA binding to target genes is mediated by basic amino acid residues at the tips of two highly conserved (40-90\%) "zinc finger" structures, formed by the tetrahedral coordination of zinc with four cysteine residues (21). The hormone-binding regions of the receptors are less well conserved, and are located at the carboxyl termini of the proteins.

\section{Multiple thyroid hormone receptors}

Following the initial isolation of TR cDNAs from chick embryo (4) and human placental (5) libraries, it has become clear

Address correspondence to Mitchell A. Lazar, M. D., Ph.D., University of Pennsylvania School of Medicine, 611 CRB, 422 Curie Blvd., Philadelphia, PA 19104-6049.

Received for publication 31 July 1990.

1. Abbreviations used in this paper: RA, retinoic acid, RAR, retinoic acid receptor; TR, thyroid hormone receptor; TRE, thyroid hormone response element.

J. Clin. Invest.

(C) The American Society for Clinical Investigation, Inc. 0021-9738/90/12/1777/06 \$2.00

Volume 86, December 1990, 1777-1782 that multiple TR-encoding mRNAs exist in a given species. These distinct TRs are divided into $\alpha$ and $\beta$ forms on the basis of sequence similarities and chromosomal localization (22-24).

$\beta$-Thyroid hormone receptors. The human placental TR, whose gene has been localized to human chromosome 3 , is the prototype $\beta$-form of TR. Studies in the rat have revealed two distinct TR $\beta$ s (Fig. 1). TR $\beta 1$ is the rat homologue of the human placental TR $\beta$, displaying 97 and $99 \%$ identity in the DNA and T3-binding domains, respectively. TR $\beta 1$ has been cloned from the GH3 pituitary cell line (25) and from liver (26) and its mRNA is expressed in most rat tissues and cell lines. The level of expression of TR $\beta 1 \mathrm{mRNA}$ is unaffected by T3 in the liver, heart, and brain of intact rats (27); however, it is up-regulated by $\mathrm{T} 3$ in the pituitary and in GH3 cells (28). In contrast, the mRNA encoding TR $\beta 2$ is down-regulated by T3 in the pituitary and in GH3 cells. Remarkably, expression of TR $\beta 2$, which was cloned from a GH3 library, has only been detected in pituitary cells (28). mRNA encoding TR $\beta 2$ has been detected in mouse pituitary (Lazar, M., R. Hodin, and W. Chin, unpublished observations, and reference 29) but to date only the rat cDNA has been isolated due to inadequate pituitary libraries from other species.

$\alpha$-Thyroid hormone receptor. $\operatorname{TR} \alpha 1$ cDNAs have been isolated from rat $(24,26,30-32)$, chick (4), human $(33,34)$, and mouse (35) libraries. The " $\alpha$ " designation was first suggested by Thompson et al. (24), who localized this TR to human chromosome 17 . TR $\alpha 1$ is $86 \%$ identical to the $T R \beta s$ in the DNA- and T3-binding domains (Fig. 1). TR $\alpha 1$ mRNA is widely expressed and is down-regulated by $\mathrm{T} 3$ in multiple tissues including heart, kidney, and pituitary, but not in brain (27, 31). The $\operatorname{TR} \alpha$ gene is complex, and encodes other members of the thyroid/steroid hormone receptor family. Alternative splicing of the TR $\alpha$ gene transcript yields a species called c-erbA $\alpha 2$ or TRvariant I (also TR $\alpha 2$, but this is misleading as discussed below) which is identical to TR $\alpha 1$ for 370 amino acids, including the DNA-binding domain, then diverges completely (Fig. 1). Human $(36,37)$, rat (30-32), and mouse (35) homologues of c-erbA $\alpha 2$ have been identified. The c-erbA $\alpha 2$ mRNA is particularly abundant in brain, and is T3regulated in a manner similar to $\operatorname{TR} \alpha 1 \mathrm{mRNA}(27,32,38)$. Mitsuhashi et al. (32) have also described a second variant (TRvII) missing the first 39 unique amino acids of the divergent sequence. An additional receptorlike molecule encoded at the TR $\alpha$ genomic locus is Rev-ErbA $\alpha$, whose mRNA contains a 269-nucleotide sequence which is complementary to cerbA $\alpha 2$ mRNA due to its transcription from the DNA strand opposite of that used to generate $\operatorname{TR} \alpha 1$ and c-erbA $\alpha 2(34,39)$.

\section{Properties of thyroid hormone receptors}

The original identification and definition of nuclear TRs was based on their high affinity and specificity for T3. The ability to manipulate putative TRs in vitro has led to even more 


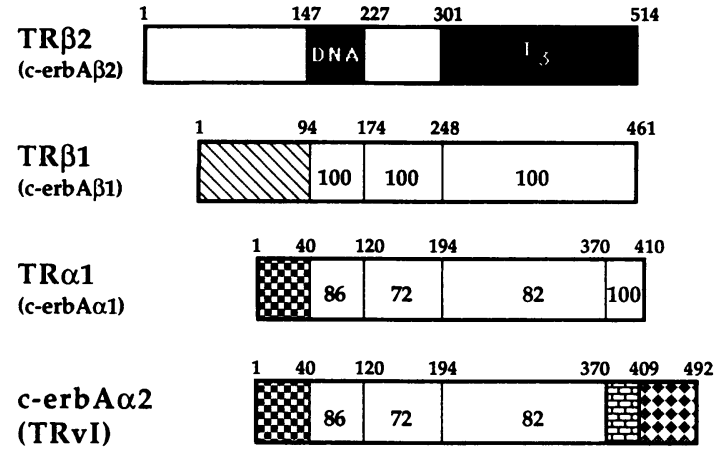

Figure 1. Thyroid hormone receptors and the carboxyl terminal variant c-erbA $\alpha 2$. The sequences deduced from rat cDNAs are depicted with the amino acids numbered above. Putative DNA- and T3-binding domains are indicated. Numbers in boxes indicate percent identity with TR $\beta 2$. Shaded boxes indicate regions which are completely dissimilar with respect to TR $\beta 2$. Amino acids $1-370$ of $\operatorname{TR} \alpha 1$ and cerbA $\alpha 2$ are identical. Amino acids 370-409 of c-erbA $\alpha 2$ (shaded differently) are lacking in another TR variant, TRvII (32).

stringent criteria. A bona fide TR must also be able to bind to thyroid hormone response element (TRE) from target genes. Furthermore, the binding of both T 3 and the TRE must be combined with an activation domain which regulates gene transcription, as is the hallmark of a productive interaction between $\mathrm{T} 3$ and its receptor.

$T 3$ binding. $\operatorname{TR} \beta 1, \operatorname{TR} \beta 2$, and $\operatorname{TR} \alpha 1$ all have been shown to bind T3 with high affinity. The reported $K_{d} \mathrm{~s}$ range between $10^{-10}$ and $10^{-11} \mathrm{M}$. Although 10 -fold differences in affinity would likely have physiological consequences, it remains to be determined whether these differences reflect variations among separate laboratories, experiments, or species, or whether they are biologically relevant. Indeed, a direct comparison of chick TR $\alpha 1$ and human TR $\beta 1$ has revealed no significant differences in affinity for $\mathrm{T} 3$, although quantitative differences in binding of the acetic acid analog (triiodoacetic acid; TRIAC) were noted (40). Preliminary experiments comparing all three TRs from a single species (rat) in our laboratories have also failed to demonstrate unique T3-binding properties.

The similar T3 binding among $\operatorname{TR} \beta 1, \operatorname{TR} \beta 2$, and $\operatorname{TR} \alpha 1$ is not surprising given the identity $(\beta 1$ and $\beta 2)$ or near-identity in T3-binding domains. However, the variant form of $\operatorname{TR} \alpha$, cerbA $\alpha 2$, has a unique carboxyl terminus which results in its inability to bind T3 (30-32). Thus, despite being encoded by a TR gene, both human and rat homologues of c-erbA $\alpha 2$ are not TRs (41). Similarly, Rev-ErbA $\alpha$, derived from the opposite strand of the TR $\alpha$ gene, does not bind T3 and is not a TR $(39,42)$.

DNA binding. T3 influences the expression of many genes to varying degrees, and thus there could be a multitude of TREs with which the TRs interact. The transcriptional activation of the rat growth hormone ( $\mathrm{rGH})$ gene by $\mathrm{T} 3$ is well established $(43,44)$, and appears to be due to a TRE located between nucleotides -208 and -163 (relative to the transcriptional start site) (45-49), although another TRE has recently been discovered in the third intron of the gene (50). Direct binding of TRs to the rGH TRE has been demonstrated in vitro by the avidin-biotin complex to DNA (ABCD) (30, 48, $51-54)$ and gel mobility shift $(47,55-58)$ assays. Interestingly, this binding appears to be independent of $\mathrm{T} 3$. When directly compared, no differences in TRE binding have been detected among the multiple TRs. c-erbA $\alpha 2$ also binds the rGH TRE in the ABCD assay (31), though to a lesser extent than the TRs. This difference correlates with an apparent inability to bind in the gel mobility shift assay (55), which is more sensitive to dissociation rate. The reduced TRE binding of c-erbA $\alpha 2$ is presumably due to its unique carboxyl terminus.

The related palindromic sequence TREpal (TCAGGTCATGACCTGA) also binds the TR and is sufficient to confer T3-responsiveness to reporter genes (59). It has been suggested that the TR may bind specifically to the sequence AGGT(C/ A)A (51) which is also present in T3-responsive and TR-binding regions of the genes encoding $\mathrm{TSH} \alpha(53,54), \operatorname{TSH} \beta(52$, 60 ), and myosin heavy chain $\alpha(30)$, although less highly related sequences appear to confer T3-responsiveness to the malic enzyme (61) and spot 14 (62) genes. This motif is similar to the responsive elements bound by other hormone receptors, and some overlap seems to occur between the most structurally related receptors. Thus, retinoic acid receptor (RAR), which is more similar to the TR than to any other receptor, can bind to TREpal (63). Furthermore, the estrogen response element present in the Xenopus vitellogenin gene is identical to TREpal except for a central three-base pair insertion, and there is evidence that the TR and estrogen receptor can interact with one another's binding site (59).

Mediation of $T 3$ action. The most physiologically relevant property of the cloned TRs is the ability to confer T3-responsiveness when expressed in cells which otherwise do not respond to T3. This requires the ability to bind both T3 and TREs, and has been demonstrated for all three TRs. The exact mechanism of these effects is unclear but, by analogy to other transcription factors $(64,65)$, the TRs may contain activation domains which interact with cellular transcription machinery. A region located in the middle portion of the TRs has recently been implicated in this regard (66).

In contrast, c-erbA $\alpha 2$ does not produce a $\mathrm{T} 3$ dependency of transcription of reporter genes bearing TREs. Rather, it inhibits the action of the TRs in a concentration- (but not T3-) dependent manner $(41,67)$. A similar dominant negative effect is caused by the $v$-erbA protein $(57,58)$. The mechanism of these effects could involve formation of inactive heterodimers or competition for binding, either to the TRE or transcriptional factors. The DNA-binding domain of $v$-erbA appears to be necessary for its inhibitory properties (57), but studies with mutated TRs suggest a role for the potential dimerization domain (discussed below) (68). Furthermore, in the absence of retinoic acid (RA), the RAR also inhibits T3-responsive gene expression, again due presumably to interference with TRE binding and/or heterodimer formation $(56,69,70)$. The unliganded receptors may actually decrease basal expression as well $(56,57,70)$. In the presence of RA, the RAR activates transcription from TRE-containing genes, consistent with its ability to bind to the TRE $(69,71)$. Interestingly, the first reported RA-responsive element, from the laminin B1 gene, is not affected by expression of a TR in the presence of T3 (72), indicating that the receptors have separate, though overlapping, DNA-binding specificities.

Other properties. Recently, in vitro formation of TR-RAR heterodimers formation has been demonstrated (63). A puta- 
tive dimerization domain, comprised of a hydrophobic "leucine-zipper"-like heptad repeat in the vicinity of the ligandbinding domain, has been identified in the TRs and RARs (68). A similar region of the estrogen receptor appears to be responsible for its homodimerization $(73,74)$. However, it remains unclear whether the TRs can form homodimers or heterodimers with each other, and whether this is required for DNA binding and/or transcriptional activation either in vitro or in vivo. Binding of the TRs to TREs does appear to be stimulated by one or more nuclear proteins whose identities and physiological functions are unknown $(55,75)$. Finally, the intracellular location of the TRs is likely to be specified by a nuclear targeting signal (76).

\section{Implications}

The isolation of multiple TRs raises the question of whether these species have different functions, as suggested by their very existence as well as by their unique patterns of expression. As discussed, no convincing functional differences have been elucidated to date, but this remains an open issue given the multitude of tissue-specific T3 effects and as yet undiscovered responsive genes. As illustrated in Fig. 1, the three TRs are least similar at their amino termini. Although this region does not appear to be required for transcriptional activation of a TREpal-containing reporter gene by TR $\beta 1$ (77), this situation may be analogous to the $A$ and $B$ forms of the progesterone receptor, which differ only in their amino termini yet differentially activate target genes (78). The amino terminal " $\tau-1$ " domain of the glucocorticoid receptor (79) also modulates transcriptional activation. Nevertheless, given the likelihood that receptors can interact with one another and with one another's response elements, subtle dissimilarities in the dimerization or DNA-binding domains of the TRs could also result in different efficiencies and specificities of transcriptional activation.

The similarity between the functions of the c-erbA $\alpha 2$ and $v$-erbA is enigmatic. Although the isolation of TRs was anticipated because of the prior demonstration of nuclear T3 binding, the discovery of c-erbA $\alpha 2$ was serendiptious and unpredicted by earlier work. Such an inhibitor of T3 action might play a developmental role, particularly in the nervous system where $\mathrm{T} 3$ is particularly important early in ontogeny. Indeed, c-erbA $\alpha 2$ mRNA is regulated during brain maturation and development (80). However, proof of the biosynthesis and biological function of c-erbA $\alpha 2$, whose mRNA is quite abundant in multiple T3-responsive adult tissues, will be necessary to fully understand its contribution to T3 action.

The isolation and characterization of TRs has also led to increased understanding of some forms of generalized thyroid hormone resistance (GTHR). In two affected families, single base mutations resulting in an amino acid substitution (glycine to arginine at amino acid 340 , or proline to histidine at amino acid 448) in the T3-binding domain of TR $\beta$ segregate with the T3-resistant phenotype $(81,82)$. The mutation at amino acid 340 has been shown to abolish the T3-binding of TR $\beta 1$ (82) and would similarly affect TR $\beta 2$, encoded at the same locus. Even in the presence of a normal TR $\beta$ allele and two normal TR $\alpha$ alleles such a mutation could produce the dominant negative phenotype (accounting for the autosomal dominant inheritance of the disease) by the same mechanism as c-erbA $\alpha 2$,

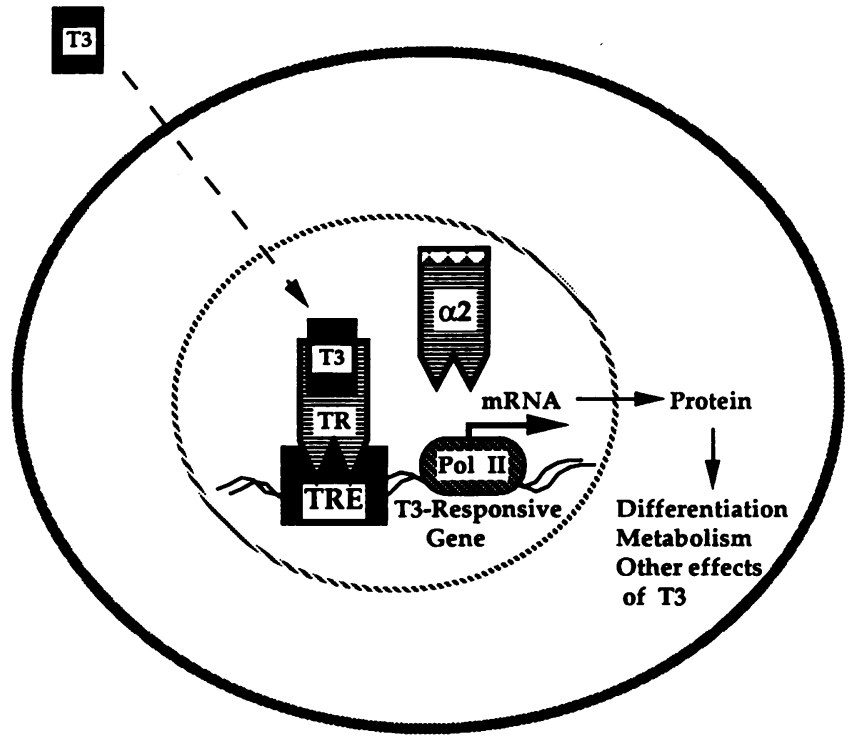

Figure 2. Model of the mediation of T3 action by nuclear thyroid hormone receptors. T3 either enters the cell (as depicted) or is derived from intracellular deiodination of T4. Nuclear interaction between a T3-bound TR and a thyroid hormone-responsive element (TRE) results in increased or decreased activity of RNA polymerase II (pol II) on a T3-responsive gene. The TRE is indicated as containing two half-sites, and the TR may bind as a dimer. Effects on mRNA levels are translated into increased or decreased cellular concentrations of proteins so as to promote differentiation, metabolic processes, and other cell-specific effects of T3. In the absence of T3, the TRE-bound TR may repress basal transcription. c-erbA $\alpha 2$ (" $\alpha 2$ "), the non-T3-binding splice variant, can inhibit the effects of T3-bound TRs by a mechanism which has not been established, probably involving heterodimer formation and/or competition for the TRE. A similar mechanism is likely to explain the dominant negative effect of the $v$-erbA oncoprotein and mutated TRs, as in the syndromes of generalized resistance to $\mathrm{T} 3$.

$v$-erbA, and mutant non-T3-binding forms of c-erbA which have been created and studied in vitro $(63,68)$. The study of other kindreds with GTHR may lead to the discovery of additional mutations, perhaps affecting TR $\alpha 1$ or involving the DNA-binding, dimerization, or other domains of the TRs.

\section{Conclusions}

In summary, our current model of the mechanism of T3 action attributes the regulation of gene transcription by $\mathrm{T} 3$ to interaction with one or more TRs acting on TREs in a wide variety of genes (Fig. 2). The actual molecular means by which T3 binding to its TR stimulates these processes remains unclear. The magnitude of the effects are related to T3 concentration, cell-type, concentration and composition of TRs, the specific TRE involved, and, perhaps, the abundance of cerbA $\alpha 2$ and unliganded receptors for other hormones. The challenge for the future will be to understand the integration of this complex array of factors in normal and pathological states.

\section{References}

1. Oppenheimer, J. H., and H. H. Samuels. 1983. Molecular Basis of Thyroid Hormone Action. Academic Press, Inc., New York. 
2. Oppenheimer, J. H., H. L. Schwartz, C. N. Mariash, W. B. Kinlaw, N. C. W. Wong, and H. C. Freake. 1987. Advances in our understanding of thyroid hormone action at the cellular level. Endocr. Rev. 8:288-308.

3. Samuels, H. H., B. M. Forman, Z. D. Horowitz, and Z.-S. Ye. 1988. Regulation of gene expression by thyroid hormone. J. Clin. Invest. 81:957-967.

4. Sap, J., A. Munoz, K. Damm, Y. Goldberg, J. Ghysdael, A. Lentz, H. Beug, and B. Vennstrom. 1986. The c-erbA protein is a high affinity receptor for thyroid hormone. Nature (Lond.). 324:635-640.

5. Weinberger, C., C. C. Thompson, E. S. Ong, R. Lebo, D. J. Gruol, and R. M. Evans. 1986. The c-erbA gene encodes a thyroid hormone receptor. Nature (Lond.). 324:641-646.

6. Graf, T., and H. Beug. 1983. Role of the v-erbA and v-erbB oncogenes of avian erythroblastosis virus in erythroid cell transformation. Cell. 34:7-9.

7. Green, S. P., P. Walter, B. Kumar, A. Krust, J.-M. Bornert, P. K. Argos, and P. Chambon. 1986. Human estrogen receptor cDNA: sequence, expression, and homology to v-erbA. Nature (Lond.). 320:134-139.

8. Weinberger, C., S. M. Hollenberg, M. G. Rosenfeld, and R. M. Evans. 1985. Domain structure of human glucocorticoid receptor and its relationship to the v-erbA oncogene product. Nature (Lond.). 318:670-672.

9. Conneely, O. M., W. P. Sullivan, D. O. Toft, M. Birnbaumer, R. G. Cook, B. L. Maxwell, T. Zarucki-Schultz, G. L. Greene, W. T. Schrader, and B. W. O'Malley. 1986. Molecular cloning of the chicken progesterone receptor. Science (Wash. DC). 233:767-770.

10. Loosfelt, H., M. Atger, M. Misrahi, A. Guiochon-Mantel, C. Meriel, F. Logeat, R. Benarous, and E. Milgrom. 1986. Cloning and sequence analysis of rabbit progesterone-receptor complementary DNA. Proc. Natl. Acad. Sci. USA. 83:9045-9049.

11. Jeltsch, M. M., Z. Krozowski, C. Quirin-Stricker, H. Gronemeyer, R. J. Simpson, J. M. Garnier, A. Krust, F. Jacob, and P. Chambon. 1986. Cloning of the chicken progesterone receptor. Proc Natl. Acad. Sci. USA 83:5424-5428.

12. Arriza, J. L., C. Weinberger, G. Cerelli, T. M. Glaser, B. L. Handelin, D. E. Housman, and R. M. Evans. 1987. Cloning of human mineralocorticoid receptor complementary cDNA: structure and functional kinship with the glucocorticoid receptor. Science (Wash. DC). 237:268-275.

13. Chang, J. C., J. Korontis, and G. Liao. 1988. Molecular cloning of human and rat complementary DNA encoding androgen receptors. Science (Wash. DC). 270:324-326.

14. Lubahn, D. B., D. R. Joseph, P. M. Sullivan, H. F. Willard, F. S. French, and E. M. Wilson. 1988. Cloning of human androgen receptor complementary DNA encoding androgen receptors. Science (Wash. DC). 240:327-330.

15. Baker, A. R., D. P. McDonnell, M. Hughes, T. M. Crisp, D. J. Mangelsdorf, M. R. Haussler, J. W. Pike, J. Shine, and B. W. O'Malley. 1988. Cloning and expression of full-length cDNA encoding human vitamin D receptor. Proc. Natl. Acad. Sci. USA 75:3294-3298.

16. McDonnell, D. P., D. J. Mangelsdorf, J. W. Pike, M. R. Haussler, and B. W. O'Malley. 1987. Molecular cloning of complementary DNA encoding the avian receptor for vitamin D. Science (Wash. DC). 235:1214-1217.

17. Petkovich, M., N. J. Brand, A. Krust, and P. Chambon. 1987. A human retinoic acid receptor which belongs to the family of nuclear receptors. Nature (Lond.). 330:444-450.

18. Giguere, V., E. S. Ong, P. Segui, and R. M. Evans. 1987. Identification of a receptor for the morphogen retinoic acid. Nature (Lond.). 330:624-629.

19. Evans, R. M. 1988. The steroid and thyroid hormone receptor superfamily. Science (Wash. DC). 240:889-895.

20. Green, S., and P. Chambon. 1986. A superfamily of potentially oncogenic hormone receptors. Nature (Lond.). 324:615-617.
21. Evans, R. M., and S. Hollenberg. 1988. Zinc fingers: gilt by association. Cell. 52:1-3.

22. Dayton, A. I., J. R. Selden, G. Laws, D. J. Dorney, J. Finan, P. Tripputi, B. S. Emanuel, G. Rovera, P. C. Nowell, and C. M. Croce. 1984. A human c-erbA oncogene homologue is closely proximal to the chromosome 17 breakpoint in acute promyelocytic leukemia. Proc Natl. Acad. Sci. USA. 81:4495-4499.

23. Spurr, N. K., S. Solomon, M. Jansson, D. Sheer, P. N. Goodfellow, W. F. Bodmer, and B. Vennstrom. 1984. Chromosomal localization of the human homologues to the oncogenes erbA and erbB. EMBO (Eur. Mol. Biol. Organ.) J. 3:159-163.

24. Thompson, C. C., C. Weinberger, R. Lebo, and R. M. Evans. 1987. Identification of a novel thyroid hormone receptor expressed in the mammalian central nervous system. Science (Wash. DC). 237:1610-1614.

25. Koenig, R., R. L. Warne, G. A. Brent, J. W. Harney, P. R. Larsen, and D. D. Moore. 1988. Isolation of a cDNA clone encoding a biolotically active thyroid hormone receptor. Proc. Natl. Acad. Sci. USA. 85:5031-5035.

26. Murray, M. B., N. D. Zilz, N. L. McCreary, M. J. MacDonald, and $\mathrm{H}$. C. Towle. 1988. Isolation and characterization of rat cDNA clones from two distinct thyroid hormone receptors. J. Biol. Chem. 263:12270-12277.

27. Hodin, R. A., M. A. Lazar, and W. W. Chin. 1990. Differential and tissue-specific regulation of multiple rat c-erbA messenger RNA species by thyroid hormone. J. Clin. Invest. 85:101-105.

28. Hodin, R. A., M. A. Lazar, B. I. Wintman, D. S. Darling, R. J. Koenig, P. R. Larsen, D. D. Moore, and W. W. Chin. 1989. Identification of a thyroid hormone receptor that is pituitary-specific. Science (Wash. DC). 244:76-79.

29. Wood, W. M., K. W. Ocran, and D. F. Gordon. 1990. An $\alpha$-subunit secreting tumor derived from thyrotropic tissue exhibits aberrant response to thyroid hormone and altered thyroid hormone receptor gene expression. In The Endocrine Society 72nd Annual Meeting, Atlanta, GA. p. 332.

30. Izumo, S., and V. Mahdavi. 1988. Thyroid hormone receptor $a$ isoforms generated by alternative splicing differentially activate myosin HC gene transcription. Nature (Lond.). 334:539-542.

31. Lazar, M. A., R. A. Hodin, D. S. Darling, and W. W. Chin. 1988. Identification of a rat c-erbA $\alpha$-related protein which binds deoxyribonucleic acid but does not bind thyroid hormone. Mol. Endocrinol. 2:893-901.

32. Mitsuhashi, T. G., G. E. Tennyson, and V. M. Nikodem. 1988. Alternative splicing generates messages encoding rat c-erbA proteins that do not bind thyroid hormone. Proc. Natl. Acad. Sci. USA. 85:5804-5808.

33. Nakai, A., A. Sakurai, G. I. Bell, and L. I. deGroot. 1988. Characterization of a third human thyroid hormone receptor coexpressed with other thyroid hormone receptors in several tissues. $\mathrm{Mol}$. Endocrinol. 2:1087-1092.

34. Miyajima, N., R. Horiuchi, Y. Shibuya, S. Fukushige, K. Matsubara, K. Toyoshima, and T. Yamamoto. 1989. Two erbA homologs encoding proteins with different $\mathrm{T} 3$ binding capacities are transcribed from opposite DNA strands of the same genetic locus. Cell. 57:31-39.

35. Prost, E., R. J. Koenig, D. D. Moore, P. R. Larsen, and R. G. Whalen. 1988. Multiple sequences encoding potential thyroid hormone receptors isolated from mouse skeletal muscle cDNA libraries. Nucleic Acid Res. 16:6248.

36. Benbrook, D., and M. Pfahl. 1987. A novel thyroid hormone receptor encoded by a cDNA clone from a human testis library. Science (Wash. DC). 238:788-791.

37. Nakai, A. S., A. Seino, A. Sakurai, I. Szilak, G. I. Bell, and L. I. deGroot. 1988. Characterization of a thyroid hormone receptor expressed in human kidney and other tissues. Proc. Natl. Acad. Sci. USA. 85:2781-2785.

38. Lazar, M. A., and W. W. Chin. 1988. Regulation of two c-erbA 
messenger ribonucleic acids in rat $\mathrm{GH} 3$ cells by thyroid hormone. $\mathrm{Mol}$. Endocrinol. 2:479-484.

39. Lazar, M. A., R. A. Hodin, D. S. Darling, and W. W. Chin. 1989. A novel member of the thyroid/steroid hormone receptor family is encoded by the opposite strand of the rat c-erbA $\alpha$ transcriptional unit. Mol. Cell. Biol. 9:1128-1136.

40. Schueler, P. A., H. L. Schwartz, K. A. Strait, C. N. Mariash, and J. H. Oppenheimer. 1990. Binding of 3,5,3'-triiodothyronine (T3) and its analogs to the in vitro translational products of c-erbA protooncogenes: differences in the affinity of the $\alpha$ - and $\beta$-forms for the acetic acid analog and failure of the human testis and kidney products to bind T3. Mol. Endocrinol. 4:227-234.

41. Lazar, M. A., R. A. Hodin, and W. W. Chin. 1989. Human carboxyl-terminal variant of $\alpha$-type c-erbA inhibits trans-activation by thyroid hormone receptors without binding thyroid hormone. Proc. Natl. Acad. Sci. USA. 86:7771-7774.

42. Lazar, M. A., K. E. Jones, and W. W. Chin. 1990. Isolation of a cDNA encoding human Rev-ErbA $\alpha$ : transcription from the non-coding DNA strand of a thyroid hormone receptor gene results in a related protein which does not bind thyroid hormone. DNA Cell. Biol. 9:77-83.

43. Spindler, S. R., S. H. Mellon, and J. D. Baxter. 1982. Growth hormone gene transcription is regulated by thyroid and glucocorticoid hormones in cultured rat pituitary tumor cells. J. Biol. Chem. 257:11627-11632.

44. Yaffe, B. M., and H. H. Samuels. 1984. Hormonal regulation of the growth hormone gene. J. Biol. Chem. 259:6284-6291.

45. Ye, Z.-S., B. M. Forman, A. Aranda, A. Pascual, B. Y. Park, J. Casanova, and H. H. Samuels. 1988. Rat growth hormone gene expression: both cell-specific and thyroid hormone response elements are required for thyroid hormone regulation. J. Biol. Chem. 263:78217829.

46. Wight, P. A., M. D. Crew, and S. R. Spindler. 1988. Sequences essential for activity of the thyroid hormone responsive transcription stimulatory element of the rat growth hormone gene. Mol. Endocrinol. 2:536-542.

47. Koenig, R. J., G. A. Brent, R. L. Warne, and P. R. Larsen. 1987. Thyroid hormone receptor binds to a site in the rat growth hormone promoter required for induction by thyroid hormone. Proc. Natl. Acad. Sci. USA. 84:5670-5674.

48. Glass, C. K., R. Franco, C. Weinberger, V. Albert, R. M. Evans, and M. G. Rosenfeld. 1987. A c-erbA binding site in the rat growth hormone gene mediates trans-activation by thyroid hormone. Nature (Lond.). 329:738-741.

49. Brent, G. A., P. R. Larsen, J. W. Harney, R. J. Koenig, and D. D. Moore. 1989. Functional characterization of the rat growth hormone promoter elements required for induction by thyroid hormone with and without a co-transfected beta-type thyroid hormone receptor. J. Biol. Chem. 264:178-182.

50. Sap, J., L. D. Magistris, H. Stunnenberg, and B. Vennstrom. 1990. A major thyroid hormone response element in the third intron of the rat growth hormone gene. EMBO (Eur. Mol. Biol. Organ.) J. 9:887-896.

51. Brent, G. A., J. W. Harney, Y. Chen, R. L. Warne, D. D. Moore, and P. R. Larsen. 1989. Mutations of the rat growth hormone promoter which increase and decrease response to thyroid hormone define a consensus thyroid hormone response element. Mol. Endocrinol. 3:1996-2004.

52. Darling, D. S., J. Burnside, and W. W. Chin. 1989. Binding of thyroid hormone receptors to the rat thyrotropin- $\beta$ gene. Mol. Endocrinol. 3:1359-1368.

53. Burnside, J., D. S. Darling, F. E. Carr, and W. W. Chin. 1989. Thyroid hormone regulation of the rat glycoprotein hormone alphasubunit gene promoter activity. J. Biol. Chem. 264:6886-6891.

54. Chatterjee, V. K. K., J.-K. Lee, A. Rentoumis, and J. L. Jameson. Negative regulation of the thyroid stimulating hormone alpha gene by thyroid hormone: receptor interaction adjacent to the TATA box. Proc. Natl. Acad. Sci. USA. 86:9114-9118.

55. Murray, M. B., and H. C. Towle. 1989. Identification of nuclear factors that enhance binding of the thyroid hormone receptor to a thyroid hormone response element. Mol. Endocrinol. 3:1434-1442.

56. Graupner, G., K. N. Wills, M. Tzukerman, X.-K. Zhang, and M. Pfahl. 1989. Dual regulatory role for thyroid-hormone receptors allows control of retinoicacid receptor activity. Nature (Lond.). 340:653-656.

57. Damm, K., C. C. Thompson, and R. M. Evans. 1989. Protein encoded by v-erbA functions as a thyroid-hormone receptor antagonist. Nature (Lond.). 339:593-597.

58. Sap, J., A. Munoz, J. Schmitt, H. Stunnenberg, and B. Vennstrom. 1989. Repression of transcription mediated at a thyroid hormone response element by the v-erbA oncogene product. Nature (Lond.). 340:242-244.

59. Glass, C. K., J. M. Holloway, O. V. Devary, and M. G. Rosenfeld. 1988. The thyroid hormone receptor binds with opposite transcriptional effects to a common sequence motif in thyroid hormone and estrogen response elements. Cell. 54:313-323.

60. Carr, F. E., J. Burnside, and W. W. Chin. 1989. Thyroid hormones regulate rat thyrotropin-beta gene promoter activity expressed in GH3 cells. Mol. Endocrinol. 3:709-716.

61. Petty, K. J., B. Desvergne, T. Mitsuhashi, and V. M. Nikodem. 1990. Identification of a thyroid hormone response element in the malic enzyme gene. J. Biol. Chem. 265:7395-7400.

62. Zilz, N. D., M. B. Murray, and H. C. Towle. 1990. Identification of multiple thyroid hormone response elements located far upstream from the rat S14 promoter. J. Biol. Chem. 265:8136-8143.

63. Glass, C. K., S. M. Lipkin, O. V. Devary, and M. G. Rosenfeld. 1989. Positive and negative regulation of gene transcription by a retinoic acid-thyroid hormone receptor heterodimer. Cell. 59:697-708.

64. Berk, A. J., and M. C. Schmidt. 1990. How do transcription factors work? Genes Dev. 4:151-155.

65. Ptashne, M. 1988. How eukaryotic transcriptional activators work. Nature (Lond.). 335:683-689.

66. O'Donnell, A. L., and R. J. Koenig. 1990. Mutational analysis identifies a new functional domain of the thyroid hormone receptor. Mol. Endocrinol. 4:715-720.

67. Koenig, R. J., M. A. Lazar, R. A. Hodin, G. A. Brent, P. R. Larsen, W. W. Chin, and D. D. Moore. 1989. Inhibition of thyroid hormone action by a nonhormone binding c-erbA protein generated by alternative mRNA splicing. Nature (Lond.). 337:659-661.

68. Forman, B. M., C. Yang, M. Au, J. Casanova, J. Ghysdael, and H. H. Samuels. 1989. A domain containing a leucine-zipper-like motif mediates novel in vivo interactions between the thyroid hormone and retinoic acid receptors. Mol. Endocrinol. 3:1610-1626.

69. Umesono, K., V. Giguere, C. K. Glass, M. G. Rosenfeld, and R. M. Evans. 1988. Retinoic acid and thyroid hormone induce gene expression through a common responsive element. Nature (Lond.). 336:262-265.

70. Brent, G. A., M. K. Dunn, J. W. Harney, T. Gulick, P. R. Larsen, and D. D. Moore. 1989. Thyroid hormone aporeceptor represses T3-inducible promoters and blocks activity of the retinoic acid receptor. New Biologist. 1:329-336.

71. Bedo, G., P. Santisteban, and A. Aranda. 1989. Retinoic acid regulates growth hormone gene expression. Nature (Lond.). 339:231234.

72. Vasios, G. W., J. D. Gold, M. Petkovich, P. Chambon, and L. J. Gudas. 1989. A retinoic acid-responsive element is present in the $5^{\prime}$ flanking region of the laminin B1 gene. Proc. Natl. Acad. Sci. USA. 86:9099-9103.

73. Kumar, V., and P. Chambon. 1988. The estrogen receptor binds tightly to its responsive element as a ligand-induced homodimer. Cell. 55:145-156.

74. Fawell, S. E., J. A. Lees, R. White, and M. G. Parker. 1990. 
Characterization and colocalization of steroid binding and dimerization activities in the mouse estrogen receptor. Cell. 60:953-962.

75. Burnside, J., D. S. Darling, and W. W. Chin. 1990. A nuclear factor that enhances binding of thyroid hormone receptors to thyroid hormone response elements. J. Biol. Chem. 265:2500-2504.

76. Dang, C. V., and W. M. F. Lee. 1989. Nuclear and nucleolar targeting sequences of c-erbA, c-myb, N-myc, p53, HSP70, and HIV tat proteins. J. Biol. Chem. 264:18019-18023.

77. Thompson, C. C., and R. M. Evans. 1989. Trans-activation by thyroid hormone receptors: functional parallels with steroid hormone receptors. Proc. Natl. Acad. Sci. USA. 86:3494-3498.

78. Tora, L., H. Gronemeyer, B. Turcotte, M. P. Gaub, and P. Chambon. 1988. The $\mathrm{N}$-terminal region of the chicken progesterone receptor specifies target gene activation. Nature (Lond.). 333:185-188.

79. Giguere, V., S. M. Hollenberg, M. G. Rosenfeld, and R. M.
Evans. 1986. Functional domains of the human glucocorticoid receptor. Cell. 46:645-652.

80. Mitsuhashi, T., and V. M. Nikodem. 1989. Regulation of expression of the alternative mRNAs of the rat $\alpha$-thyroid hormone receptor gene. J. Biol. Chem. 264:8900-8904.

81. Usala, S. J., G. E. Tennyson, A. E. Bale, R. W. Lash, N. Gesundheit, F. E. Wondisford, D. Accilli, P. Hauser, and B. D. Weintraub. 1990. A base mutation of the c-erbA beta thyroid hormone receptor in a kindred with generalized thyroid hormone resistance. Molecular heterogeneity in two other kindreds. J. Clin. Invest. 85:93100.

82. Sakurai, A., K. Takeda, K. Ain, P. Ceccarelli, A. Nakai, S. Seino, G. I. Bell, S. Refetoff, and L. J. DeGroot. 1989. Generalized resistance to thyroid hormone associated with a mutation in the ligand-binding domain of the human thyroid hormone receptor beta. Proc. Natl. Acad. Sci. USA. 86:8977-8981. 